\title{
Pengaruh Kualitas Pelayanan Terhadap Kepuasan Mahasiswa Mengenai Web Fikom UNISBA
}

\author{
Zulfa Haitan Rachman \\ Fakultas Ekonomi dan Bisnis, Universitas Padjadjaran Bandung \\ Jalan Dipatiukur no.35, Kota Bandung \\ iffahr13@gmail.com
}

\begin{abstract}
The phenomenon that is happening right now is that private tertiary institutions have become something that is very much needed by the community, due to the progress of the nation. Where quality universities are seen literally by the public from the facilities and infrastructure that are owned and the satisfaction of students who are in the college environment itself. So students are able to achieve the desired goals. In this case the purpose of this study is to find out how much influence the quality of service on student satisfaction regarding the Faculty of Communication Science Unisba. Service quality consists of five dimensions, namely Reliability, Responsiveness, Assurance, Empathy, and Tangibles. The sample used in this study was 40 respondents which were students of Fikom Unisba. Then the data collection in the field using online questionnaires, distributed through online media. Data analysis technique used in this study is to use SPSS. The results showed that service quality had a significant (significant) effect on student satisfaction. From the output obtained a coefficient of determination (R2) of 0.215 which implies that the influence of the independent variable (service quality) on the dependent variable (student satisfaction).
\end{abstract}

Keywords- Service Quality; Student Satisfaction.

\begin{abstract}
Abstrak- Fenomena yang terjadi saat ini yaitu perguruan tinggi swasta menjadi sesuatu yang sangat dibutuhkan oleh masyarakat, karena untuk kemajuan bangsa. Dimana perguruan tinggi yang berkualitas dilihat secara harfiah oleh masyarakat dari sarana dan prasarana yang dimiliki serta kepuasan mahasiswa yang berada di dalam lingkungan perguruan tinggi itu sendiri. Sehingga mahasiswa mampu mencapai tujuan yang diinginkan. Dalam hal ini tujuan penelitian ini yaitu untuk mengetahui seberapa besar pengaruh kualitas pelayanan terhadap kepuasan mahasiswa mengenai web Fikom Unisba. Kualitas pelayanan terdiri dari lima dimensi yaitu Reliability, Responsiveness, Assurance, Empathy, dan Tangibles. Sampel yang digunakan dalam penelitian ini adalah 40 responden yang dimana mahasiswa Fikom Unisba. Kemudian pengumpulan data dilapangan dengan menggunakan angket secara online, disebarkan melalui media online. Teknik analisis data yang digunakan dalam penelitian ini yaitu dengan menggunakan SPSS. Hasil penelitian menunjukkan kualitas pelayanan berpengaruh nyata(signifikan) terhadap kepuasan mahasiswa. Dari output tersebut diperoleh koefisien determinasi (R2) sebesar 0,215 yang mengandung pengertian bahwa pengaruh variabel bebas (kualitas pelayanan) terhadap variabel terikat (kepuasan mahasiswa).
\end{abstract}

Kata Kunci- Kualitas Pelayanan; Kepuasan Mahasiswa.

\section{PENDAHULUAN}

Perguruan tinggi merupakan salah satu lembaga penyelenggara pendidikan tinggi yang turut serta dalam mencerdaskan kehidupan fondasi bagi suatu negara. Perguruan tinggi diharapkan bisa mencetak lulusan-lulusan yang terbaik dan mempunyai daya saing baik di nasional maupun internasional. Sehingga dalam hal ini untuk menghasilkan lulusan yang berkualitas dan mempunyai daya saing, maka perguruan tinggi institusi pendidikan harus bisa memberikan pelayanan akademik yang berkualitas. Pendidikan merupakan sesuatu yang berlangsung secara terus menerus sejak seseorang masih berada dalam lingkungan keluarga tersebut (Seniati,2006).

Perguruan tinggi swasta merupakan salah satu alternatif untuk menghadapi fenomena meningkatnya permintaan masyarakat terhadap kebutuhan pendidikan tinggi saat ini. Seiring dengan perkembangan teknologi, apalagi menjadi negara yang berkembang membuat penduduk Indonesia semakin dekat dengan teknologi. Dengan meningkatnya peran perguruan tinggi dalam mendukung program pemerintah untuk meningkatkan kualitas hidup dengan memperoleh pendidikan yang layak. Sehingga perguruan tinggi terus menerus meningkatkan kualitas pelayanan yang diberikan kepada mahasiswa.

Dalam hal ini program Studi Ilmu Komunikasi yang disusun dan diarahkan untuk mewujudkan tujuan Unisba, yaitu melalui proses akademik yang intensif, hendak dihasilkan insan - insan akademis. Program studi ilmu komunikasi merupakan salah satu jurusan favorit di Unisba. Kecenderungan positif tersebut terus diusahakan diimbangi dengan peningkatan sarana belajar yang semakin memadai. 
Sehingga dapat menyesuaikan diri dengan perkembangan bidang komunikasi yang cepat.

Website Fikom Unisba menyediakan informasi yang berkaitan dengan tugas dan fungsi dari institusi yang bersangkutan. Satu hal yang dapat menjadi nilai tambah adalah dapat menyediakan informasi yang valid dan dapat dipercaya kepada penggunanya. Dengan adanya web fikom unisba maka dapat memberikan pelayanan yang dapat memberikan kepuasan kepada mahasiswa. Sehingga dapat memudahkan mahasiswa dalam mendapatkan informasi melalui web Fikom Unisba.

Fenomena yang terjadi saat ini, perguruan tinggi swasta kurang memperhatikan kualitas pelayanan yang dibutuhkan oleh mahasiswa. Padahal sistem teknologi sudah dipakai untuk menyediakan fasilitas mahasiswa dari sarana dan prasarana yang dimiliki di perguruan tinggi swasta itu sendiri. Kandampully (2000) menyatakan bahwa kualitas layanan memiliki peran untuk kesuksesan bisnis jasa. Pelanggan memiliki kesempatan untuk menilai secara kritis kualitas jasa yang disediakan. Pelanggan akan menilai kualitas pelayanan dengan membandingkan antara pelayanan yang diperoleh dengan pelayanan yang diharapkan. Sehingga pelanggan mampu memberikan complain, apabial tidak sesuai dengan ekspektasi.

Penelitian telah menegaskan bahwa kualitas pelayanan merupakan faktor pendukung kepuasan (Cronin dan Taylot,1992; Shemwell et al,1998). Mahasiswa merupakan salah satu stakeholder yang sangat penting dari kualitas pendidikan. Tanpa adanya mahasiswa berperan, maka kualitas pendidikan tidak dapat dinilai. Oleh karena itu, penulis memilih melakukan penelitian lebih lanjut mengenai kualitas layanan terhadap kepuasan mahasiswa mengenai web Fikom Unisba khususnya untuk mahasiswa angkatan 2015,2016, dan 2017. Tujuan dari penelitian ini adalah untuk mengetahui pengaruh service quality akademik web Fikom Unisba berpengaruh terhadap kepuasan mahasiswa Fikom Unisba.

\section{KAJIAN PUSTAKA}

Dalam hal ini kualitas pelayanan mengacu pada penilaian konsumen terhadap inti dari pelayanan, penyedianya. Kualitas layanan dapat diartikan sebagai upaya pemenuhan kebutuhan dan keinginan konsumen serta ketepatan penyampaiannya dalam mengimbang harapan konsumen, karena konsumen berhak untuk menentukan kualitas layanan (Tjiptono,2007:118). Berbagai peneliti telah memberikan temuan mengenai perhatian mahasiswa terhadap kualitas dan penggunaan siswa untuk mengukur kualitas layanan yang disediakan. Mahasiswa harus dinilai sebagai produk dalam suatu institusi bukan yang lain (Emery et al,2001).

Menurut Parasuraman,Zeithaml, dan Berry (dikutip oleh Tjiptono,2008) kompetensi,kesopanan, kredibilitas, dan keamanan disatukan menjadi jaminan (assurance). Dengan demikian terdapat lima dimensi utama yang disusun sesuai urutan tingkat kepentingan relatifnya sebagai berikut:

1. Reliability, kemampuan perusahaan untuk menyampaikan layanan yang dijanjikan secara akurat pertama kali. Sehingga nantinya akan jelas.

2. Responsiveness, kesedian dan kemampuan penyedia layanan untuk membantu para pelanggan dan merespon permintaan mereka dengan cepat, tanpa adanya sedikit keterlambatan dalam menyampaikan informasi.

3. Assurance, kemampuan mereka dalam menanam kepercayaan dan kerahasiaan adalah diperlukan dalam pelayanan. Data- data yang disimpan secara rahasia.

4. Empathy, bertindak demi kepentingan pelanggan, serta memberikan perhatian personal kepada para pelanggan.Apabila terdapat kesalahan. Maka karyawan akan segera memberikan respon dengan baik.

5. Tangibles, berkenaan dengan penampilan fisik fasilitas layanan.

Kepuasan adalah tingkat perasaan seseorang setelah membandingkan kinerja/hasil yang dirasakannya dengan harapannya mampu sesuai dengan harapan (Oliber,1980) dikutip oleh Supranto (2011). Tingkat kepuasan merupakan fungsi dari perbedaan antara kinerja yang dirasakan dengan harapan. Sehingga nantinya tingkat kepuasan mengetahui apakah sesuai dengan harapan atau tidak.

Sementara Sarjono (2007) kepuasan mahasiswa adalah perbandingan antara harapan yang diinginkan mahasiswa tentang pelayanan karyawan, kompetensi dosen yang didukung oleh sarana prasarana dan kepemimpinan dengan apa yang mahasiswa rasakan setelah mendapatkan pelayanan.

Persepsi kualitas menciptakan citra positif di pikiran yang akhirnya membawa mereka ke kepuasan dan mampu tercapai sesuai dengan keinginan (Alves dan Raposo,2010). Apabila harapan pelanggan tidak sesuai dengan yang diharapkan, maka akan timbul pada sifat negatif yaitu dimana timbulnya keluhan 
atau complain. Dalam hal ini kualitas website akan sangat berpengaruh terhadap tingkat kepuasan. Semakin tinggi kualitas suatu web, maka nantinya akan semakin banyak pengguna yang mengakses website tersebut (Budi,2013).

Berdasarkan uraian diatas, maka dihipotesiskan :

H1: Kualitas pelayanan berpengaruh terhadap kepuasan mahasiswa.

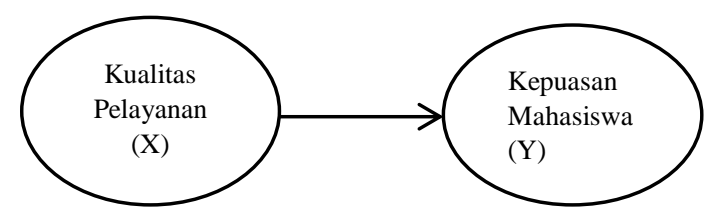

\section{METODE PENELITIAN}

Dalam hal ini metode yang digunakan dalam penelitian yaitu metode kuantitatif. Populasi dalam penelitian ini mahasiswa Fikom Unisba angkatan 2015,2016, dan 2017. Maka, data secara keseluruhan dalam penelitian ini, terdapat 40 responden yang menjawab penelitian. Sehingga jumlah sampel yang digunakan dalam penelitian ini adalah sebanyak 40 responden. Metode pengumpulan data merupakan salah satu aspek yang berperan dalam kelancaran dan keberhasilan dalam suatu penelitian. Sehingga dalam penelitian ini metode pengumpulan data yang digunakan adalah Studi Pustaka dan kuesioner (Angket). Kemudian teknik analisis data yang digunakan dalam penelitian ini adalah dengan menggunakan SPSS for Windows Ver. 21.0.

\section{HASIL DAN PEMBAHASAN}

\section{Model Summary}

\begin{tabular}{|l|l|l|l|l|}
\hline Model & $\mathrm{R}$ & R Square & $\begin{array}{l}\text { Adjusted } \\
\text { Square }\end{array}$ & $\begin{array}{l}\text { Std. Error of } \\
\text { the Estimate }\end{array}$ \\
\hline 1 &, $769^{\mathrm{a}}$ &, 591 &, 580 & 1,328 \\
\hline
\end{tabular}

Predictors: (Constant), Kualitas Pelayanan

\section{Output (Model Summary)}

Dalam hal ini tabel diatas menjelaskan bahwa besarnya korelasi atau hubungan (R) yaitu sebesar 0,769 dan kemdudian dijelaskan besarnya presentase pengaruh variabel bebas terhadap variabel terikat yang disebut koefisien determinasi yang merupakan hasil dari penguadratan $R$. Dari output tersebut diperoleh koefisien determinasi (R2) sebesar 0,215 yang mengandung pengertian bahwa pengaruh variabel bebas (Kualitas Pelayanan) terhadap variabel terikat (kepuasan mahasiswa) adalah sebesar 0,591 atau 59,1 \%, sedangkan sisanya dipengaruhi oleh variabel yang lain.

ANOVA

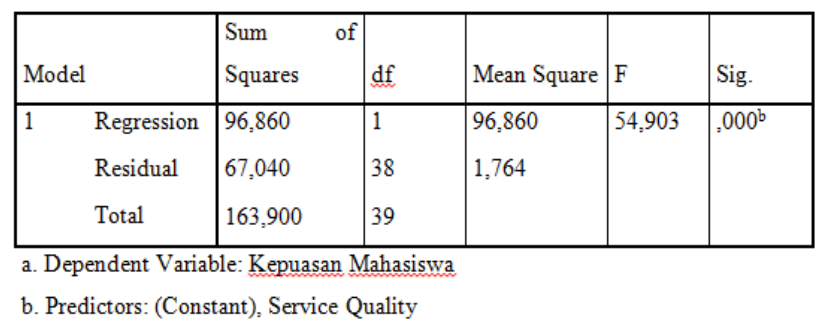

Dalam hal ini untuk menjelaskan apakah ada pengaruh antara yang nyata (signifikan ) variabel kualiatas pelayanan (x) terhadap kepuasan mahasiswa (y). Dari output bahwa F hitung = 54,903 dengan tingkat signifikansi atau probabilitas $0,000<0,005$, maka model regresi yang dapat dipakai untuk memprediksi variabel kepuasan mahasiswa.

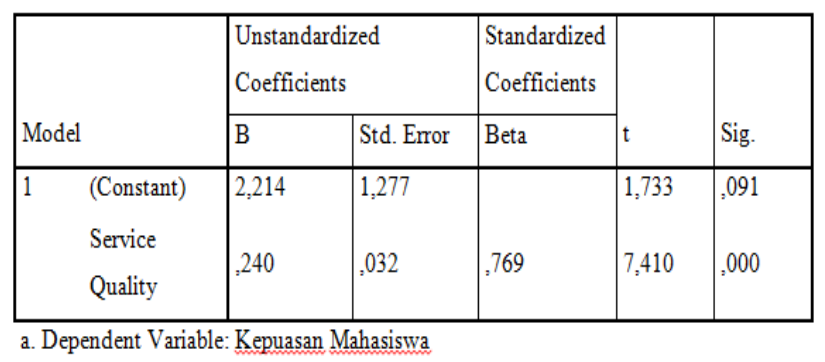

\section{Output (Coeffiecient)}

Pada constant (a) yaitu 2,214, sedangkan nilai kualitas pelayanan (b) adalahh 0,240. Sehingga persamaan regresinya dapat ditulis: $\mathrm{Y}=\mathrm{a}+\mathrm{bX}$ atau $\mathrm{Y}=$ 2,214+0,240X

Dalam hal ini koefisien b dinamakan koefisien arah yang regresi dan menyatakan perubahan rata- rata variabel Y untuk setiap perubahan variabel X sebesar satu satuan. Perubahan ini merupakan pertahanan nilai $b$ bertanda postif dan penurunan, apabila $b$ bertanda negatif. Sehingga dari persamaan tersebt dapat diinterpretasikan yaitu:

1. Konstanta sebesar 2,241 menyatakan bahwa, jika tidak ada nilai kualitas pelayanan maka nilai kepuasan mahasiswa sebesar 2,241.

2. Koefisien regresi X (kualitas pelayanan) sebesar 0,240 menyatakan bahwa setiap penambahan 1 nilai kualitas pelayanan, maka nilai kepuasan mahasiswa bertambah sebesar 0,240. 
Selain itu juga dari output diatas dapat diketahui bahwa nilai $\mathrm{t}$ hitung $=7,410$ dengan nilai signifikansi $0,000<0,05$. Sehingga H0 ditolak dan H1 diterima yaitu itu artinya bahwa ada pengaruh yang nyata (siginifikan) variabel kualitas pelayan (X) terhadap kepuasan mahasiswa (Y).

\section{KESIMPULAN DAN SARAN}

Dalam hal ini bahwa website saat ini sangat penting untuk menjadi fasilitas di perguruan tinggi swasta, karena dengan perkembangan teknologi yang begitu cepat dan untuk memudahkan para mahasiswa dalam mendapatkan informasi dan untuk memudahkan juga untuk megetahui jadwal perkuliahan dan hal lainnya. Hasil penelitian menunjukkan bahwa kelima dimensi pembentuk kualitas layanan terbukti berpengaruh secara siginifikan terhadap kepuasan mahasiswa mengenai web Fikom Unisba. Dimensi terkuat dalam menjelaskan kualitas layanan berturut- turut adalah reliability, responsiveness, assurance,empathy dan tangibles. Selain itu, hasil menunjukkan kualitas pelayanan berpengaruh nyata(signifikan) terhadap kepuasan mahasiswa. Dari output tersebut diperoleh koefisien determinasi (R2) sebesar 0,215 yang mengandung pengertian bahwa pengaruh variabel bebas (kualitas pelayanan) terhadap variabel terikat (kepuasan mahasiswa).

\section{REFERENSI}

[1] Alves, H. dan Raposo, M. 2010. The Influence of University Image on Students Behavior. International Journal of Educational Management, 24 (1): 73-85.

[2] Budi, R. F. 2013. Pengaruh Kualitas Web Terhadap Tingkat Kepuasan Penggunaan Google Scholar (Studi Pada Mahasiswa Unair
Sebagai Penunjang Kegiatan Akademis). Libri-Net, 2(1), 1-5.

[3] Cronin, J. J. Jr., dan Taylor, S. A. 1992. Measuring Service Quality: a Reexamination and Extension. Journal Marketing, 56 (3): 5568.

[4] Emery, C. Kramer, T. dan Tian, R. 2001. Customer vs. Product: Adopting an Effective Approach to Business Students. Quality Assurance Education, 9(2): 110-115.

[5] Kandampully, J. 2000. The Impact of Demand Fluctuation on the Quality of Service: A tourism Industry Example. Managing Service Quality, 10(1): 10-18.

[6] Seniati, Liche. 2006. Pengaruh Masa Kerja, Trait Kepribadian, Kepuasan Kerja, dan Iklim Psikologis Terhadap Komitmen Dosen pada Universitas Indonesia, Makara, Sosial Humaniora, 10(2): 88-97.

[7] Shemwell, D. J., Yavas, U., dan Bilgin, Z. 1998. Customer Service Provider Relationship: an Empirical Test of A Model of Service Quality, Satisfaction and Relationship Oriented Outcomes. International Journal Service Industry Management, 9 (2): 155-168.

[8] Supranto, J. 2011. Pengukuran Tingkat Kepuasan Pelanggan Untuk Menaikkan Pangsa Pasar. Jakarta: Rineka Cipta.

[9] Sarjono, Yetty, 2007, Faktor- Faktor Strategik Pelayanan Dosen dan Dampaknya Terhadap Kepuasan Mahasiswa FKIP Universitas Muhamadiyah Surakarta Tahun Akademik 2005-2006, Varidika, Vol. 19, No. 1, 2007.

[10] Tjiptono, F. 2007. Strategi Pemasaran. Edisi Pertama. Yogyakarta: Andi Offset.

[11] Tjiptono, Fandy. 2008. Service Management. Yogyakarta: PT Andi. 